\title{
7. HIGH-RESOLUTION COMPRESSIONAL-WAVE VELOCITY MEASUREMENTS IN PLEISTOCENE SEDIMENTS OF THE CEARA RISE (WESTERN EQUATORIAL ATLANTIC): IMPLICATIONS FOR ORBITAL DRIVEN SEDIMENTARY CYCLES ${ }^{1}$
}

\author{
J. Grützner, ${ }^{2}$ F.C. Bassinot, ${ }^{3}$ and J. Mienert ${ }^{2}$
}

\begin{abstract}
Cores from Ocean Drilling Program Sites 927 and 928, retrieved in water depths of $3315 \mathrm{~m}$ and $4012 \mathrm{~m}$ on the northern flank of the Ceara Rise, were examined to provide continuous time series of compressional-wave velocity for the Pleistocene $(0-1.2 \mathrm{Ma})$, to evaluate the responses of these records to climate change in the time and frequency domain and to study the effect of carbonate dissolution on $P$-wave velocity changes.

Comparisons with other high-resolution sediment physical property measurements (GRAPE density, magnetic susceptibility) and sedimentological parameters $\left(\mathrm{CaCO}_{3}\right.$ content, coarse fraction) demonstrate that velocity changes at Sites 927 and 928 are the result of glacial/interglacial changes in coarse-fraction grain size, with velocity increasing as grain size increases during interglacial periods. The grain-size distribution in turn is controlled by carbonate productivity and dissolution changes. This signal, however, is diluted by abundant input of fine-grained terrigenous sediments from the Amazon Fan that contain magnetic minerals and thus lead to an inverse relationship between velocity and magnetic susceptibility.

Spectral analysis of $P$-wave velocity and related parameters reveals that spectral energy is concentrated at orbital frequencies in the precession, obliquity, and eccentricity band, and, therefore, confirms the potential of velocity records as a paleoceanographic tool. Marked differences between variance density spectra of the velocity and preservation index records at Site 927 indicate that velocity changes in sediments deposited well above the present lysocline - apart from the dilution effect-most probably reflect foraminifer productivity changes. At Site 928, enhanced dissolution close to the lysocline affects the velocity time series and leads to maxima of concentration in variance density between obliquity and precessional frequency bands.
\end{abstract}

\section{INTRODUCTION}

With the development of automated devices allowing rapid and non-destructive measurements of physical properties at resolutions of about 1-5 cm, parameters like GRAPE (Gamma-Ray Attenuation Porosity Evaluator) density, magnetic susceptibility and compressional-wave velocity have become extremely valuable in paleoceanographic, paleoclimatic, and stratigraphic studies. For instance, some time scales presented in this volume have been derived from orbital tuning of the magnetic susceptibility records obtained during Leg 154 (e.g., Bickert et al., Chapter 15, this volume; Shackleton and Crowhurst, this volume).

Despite the fact that magnetic susceptibility and GRAPE records have been used widely (e.g. Mayer, 1991, Robinson et al., 1995), far fewer studies have been carried out on high-resolution $P$-wave velocity measurements. The potential of these records for paleoceanographic purposes has been clearly demonstrated (Mienert, 1986). $P$ wave velocities measured in late Pleistocene equatorial pelagic sediments from the Pacific (Mayer, 1980), the Indian (Bassinot, 1993) and Atlantic Ocean (Mienert et al., 1988) have been used to resolve glacial-interglacial climatic cycles. Mayer (1980) showed that spatial and temporal changes in carbonate dissolution cause a decrease in sand-sized grains, which results in a decrease in compressional-wave velocity. Mienert et al. (1988) emphasized the stratigraphic potential of acoustic records in uncemented pelagic carbonates by correlating $P$-wave velocity profiles from the western to the eastern equatorial Atlantic. In the tropical Indian Ocean, Bassinot (1993) was able to

${ }^{1}$ Shackleton, N.J., Curry, W.B., Richter, C., and Bralower, T.J. (Eds.), 1997. Proc. ODP, Sci. Results, 154: College Station, TX (Ocean Drilling Program).

GEOMAR Forschungszentrum für marine Geowissenschaften, Wischhofstraße 1-

3, D-24148 Kiel, Federal Republic of Germany. jgruetzner@geomar.de

${ }^{3}$ Centre des Faibles Radioactivités, CNRS/CEA, Avenue de la Terrasse BP 1, 91198 Gif-sur-Yvette, France. track velocity cycles caused by dissolution pulses over a distance of $1700 \mathrm{~km}$ from the Madingley Rise to the Maldives archipelago.

Generally, climatic cycles are mirrored by changes in production and dissolution of biogenic carbonate and by changes in terrigenous sediment fluxes. These depositional processes determine the relative proportions of sediment components and their grain size distributions, which in turn control the physical properties of the sediment.

The Pleistocene sediments covering the Ceara Rise are predominantly pelagic oozes consisting of biogenic carbonate particles (calcareous nannofossils, foraminifers) diluted by abundant terrigenous clays transported from the Amazon River. Mienert et al. (1988) demonstrated that $P$-wave velocity changes in Ceara Rise sediments, measured in piston cores retrieved from above the present lysocline, parallel past changes in carbonate accumulation and sediment coarse fraction and thus co-vary with changes from glacial to interglacial climate. Furthermore, Mienert and Bloemendal (1989) showed that $P$ wave velocity and magnetic susceptibility are inversely correlated in Ceara Rise sediments. High $P$-wave velocities and low magnetic susceptibilities are associated with interglacials and vice versa during glacials. In sediments deposited below the present lysocline the glacial/interglacial amplitude contrasts in $P$-wave velocity disappear as a result of enhanced dissolution of carbonates.

All of the velocity papers cited so far are based on measurements obtained with sonic velocity probes that were inserted into the sediments of split cores. A tool to perform high-resolution acoustic measurements more rapidly through the whole core (the $P$-wave logger, PWL) has existed aboard JOIDES Resolution since Ocean Drilling Program (ODP) Leg 108 (Schultheiss et al., 1988). The velocity records measured during Leg 108 were successfully used for correlations between holes and for local inter-site correlations. But since these early studies there have been no other publications on high-resolution velocity changes appearing in ODP-related literature, probably because of the fact that the PWL velocity measurements are often very noisy and were therefore omitted for detailed work. 
The purposes of this paper are (1) to provide continuous high-resolution PWL velocity records for upper Pleistocene sediments (0-1.2 Ma) of the western equatorial Atlantic; (2) to evaluate the potential of these velocity records for paleo-oceanographic and paleoclimatic reconstructions in comparison to GRAPE and magnetic susceptibility measurements; (3) to explore and compare the responses of physical property records to orbital forcing; and 4) to study the effects of carbonate dissolution on sonic velocity.

The work concentrates on the shallow Site 927 in a water depth of 3315 meters and a deeper Site 928 drilled in a water depth of $4012 \mathrm{~m}$ (Fig. 1), which is close to the present lysocline $(\sim 4300 \mathrm{~m})$. Three holes were drilled at both sites. These holes provided a complete re- covery of the sedimentary sequence to 266 mbsf at Site 927 and to $190 \mathrm{mbsf}$ at Site 928.

\section{METHODS}

The methods used to perform continuous and discrete measurements on the Pleistocene sections of Sites 927 and 928 are described briefly. For more detailed information we refer to the "Physical Properties" section of the "Explanatory Notes" chapter of the Initial Reports volume for Leg 154 (Curry, Shackleton, Richter, et al., 1995) and to Schultheiss and McPhail (1989). Only the processing se-

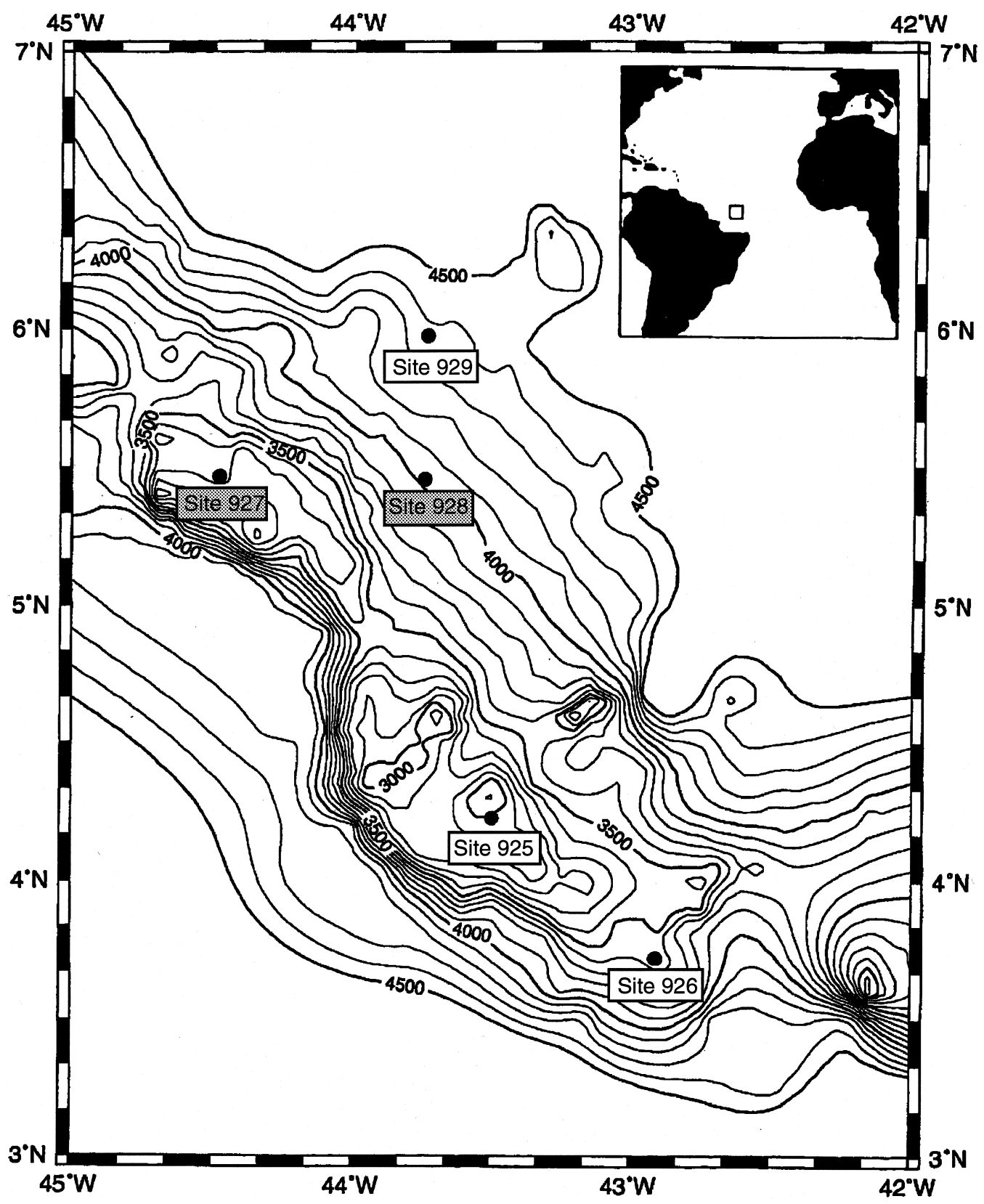

Figure 1. Location of the five sites drilled on Ceara Rise during Leg 154. Our investigations concentrate on Site 927 (water depth $3315 \mathrm{~m}$ ) and Site 928 (water depth $4012 \mathrm{~m}$ ) 
quence for the construction of high-resolution velocity splices is presented in detail.

\section{Measurements with the Multisensor Track (MST)}

During Leg 154, high-resolution physical property measurements were made at all sites with the Multisensor Track (MST). The $P$ wave logger (PWL) is mounted on the MST, together with the GRAPE, magnetic susceptibility, and natural gamma devices.

The PWL measures the speed of a $500 \mathrm{kHz}$ compressional-wave pulse (repetition rate $1 \mathrm{kHz}$ ) travelling through a whole core liner filled with sediment. A pulse-detecting system measures the traveltime of a wave between transmitting and receiving transducers with a resolution of $50 \mathrm{~ns}$. The distance between the $P$-wave transducers, which are aligned perpendicular to the core axis, is monitored by a pair of displacement transducers. The application and use of the PWL has been discussed in detail by Schultheiss et al. (1988) and Schultheiss and McPhail (1989). During Leg 154 measurements were taken at 2-cm intervals on APC and relatively undisturbed XCB cores corresponding to a time resolution of about 300-600 years.

Wet bulk densities (GRAPE densities) were calculated from gamma-ray attenuation (Boyce, 1976), measured at 1-cm intervals allowing for a time resolution of about $150-300$ years. A scintillation detector measures the attenuation through the sediment core of gamma rays emitted by a ${ }^{137} \mathrm{Cs}$ source. The data were corrected for different attenuation coefficients of solids and fluids in the sample, using a method suggested by Boyce (1976).

Magnetic susceptibility measurements were made using the Bartington MS1 loop sensor at 3-cm intervals, allowing for a time resolution of about 450-900 years. Data were archived in raw instrument units ("cgs" mode) that require a single multiplicative factor of $7.7 \times$ $10^{-6}$ to convert to volume-normalized SI units.

Continuous high-resolution data sets of susceptibility measurements were constructed aboard the drill ship (Curry, Shackleton, Richter, et al., 1995) by splicing the records from adjacent parallel holes. Splicing of the GRAPE and PWL data sets as part of this study was done on shore.

For time series comparison and calculation of frequency spectra, MST physical property records were detrended to remove lower frequency variability, which is presumably not associated with climatic changes.

\section{Discrete Velocity Measurements}

Discrete compressional-wave velocity measurements in soft sediment were obtained using a Digital Sound Velocimeter (DSV) from Dalhousie University/Bedford Institute of Oceanography. Velocity calculations were based on accurate measurement of the travel time of an acoustic signal between pairs of piezoelectric transducers inserted in the split sediment core (Mayer et al., 1987). Velocities were measured along and across the core axis at a sampling rate of about one measurement per $1.5 \mathrm{~m}$ of core length.

\section{Construction of Continuous High-Resolution Velocity Records from the Ceara Rise}

Several factors influence the data quality of acoustic measurements obtained made with the PWL; thus, it was necessary to edit and correct the data before constructing a high-resolution splice record. Fig. 2 illustrates the sequential data processing applied to Leg 154 PWL data. If the signal is strongly attenuated, the determination of the travel time is inaccurate, and anomalously high or low velocities are calculated (Fig. 2A). The compressional-wave pulse has to propagate through the sediments with a sufficiently high amplitude. Rea- sons for strong signal attenuation are (1) bad coupling between transducers and liner; (2) bad coupling between the sediment and the inner liner wall if the liner is not filled completely with sediments; and (3) presence of gas in the sediments (Schultheiss and McPhail, 1989). To remove these erroneous measurements from the data set, the signal amplitudes, which are recorded in digital units from 0 to 255 , were used as a quality indicator. Velocity measurements with amplitudes less than 180 were anticipated as unreliable and removed automatically from the data set. The remaining erroneous data excursions were identified and removed manually after plotting the velocity data vs. depth (mbsf). However, at the end of each section abrupt shifts in average velocity occur (Fig. 2B). These shifts might be a result of insufficient adjustment and calibration of the displacement transducers. This artifact also may explain the sometimes marked differences that were observed between PWL measurements and discrete velocity measurements (Fig. 2B).

To correct the PWL measurements for each hole, we adjusted the continuous velocity data to the linear velocity vs. depth (in mcd) trend obtained from all discrete measurements at one site (Fig. 2C). From the linear regression function we calculated the "expected" velocity for the midpoints of each measured section and also computed the average measured PWL velocity for each section. The ratio of expected to average velocity then gives the correction factor for every PWL measurement of a particular section. After this correction procedure the PWL velocity records of parallel holes (Fig. 2D) were merged to construct high-resolution splices (Fig. 2E) vs. composite depth (mcd) for Sites 927 and 928.

Although relative velocity changes caused by variations in sedimentary input were recorded accurately, we must stress that data quality is not optimal and absolute velocity values might be less exact because of the various corrections applied during the data processing. We believe that the quality of PWL velocity data could be much improved by careful calibration of the system and more often repeated measurements of standards with different velocities (e.g., distilled water, aluminum). Besides the calculated velocity and the signal amplitude, the actual measured values of traveltime and displacement should be included in the output data set for easier identification and correction of systematic errors. The described data handling sequence actually is a time-consuming process but could be much accelerated for shipboard use with available splicing software (Hou and Mayer, 1995; deMenocal and King, 1995).

\section{Other Relevant Measurements}

To evaluate the sedimentological parameters that control $P$-wave velocity changes the grain size distribution and carbonate content of 240 samples from Hole 927A were measured. The percentage sand fraction $(>63 \mu \mathrm{m})$ was calculated after wet sieving and drying of the bulk sample. A visual examination revealed that the coarse fraction consisted exclusively of foraminifers. Carbonate content was determined using a LECO-125 system (Boyce and Bode, 1972). Additional grain-size and carbonate data for Sites 927 and 928 were kindly provided by colleagues (W.B. Curry, Woods Hole Oceanographic Institution; J.L. Cullen, Salem State College; T. Bickert, University of Bremen; and E. Vincent, Laboratoire de Géologie du Quaternaire, Marseille). The downhole sampling resolution of these combined data sets of carbonate and grain size determinations varies between 1 and $10 \mathrm{~cm}$. The average sample interval is $7 \mathrm{~cm}$ at Site 927 and $9 \mathrm{~cm}$ at Site 928 allowing for a time resolution of 1.5 and 2.4 k.y. respectively.

The ratio of coarse fraction content to carbonate content (in wt $\%$ ) was used as a preservation (dissolution) indicator, with the assumption that the sediment coarse fraction consists exclusively of foraminifers. Shells of foraminifers are weakened by partial dissolution and 
SITE 927

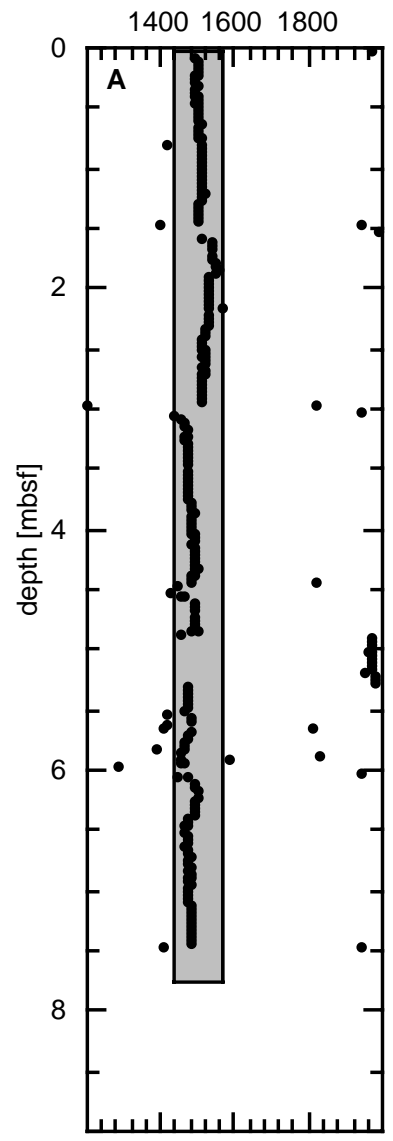

148015201560

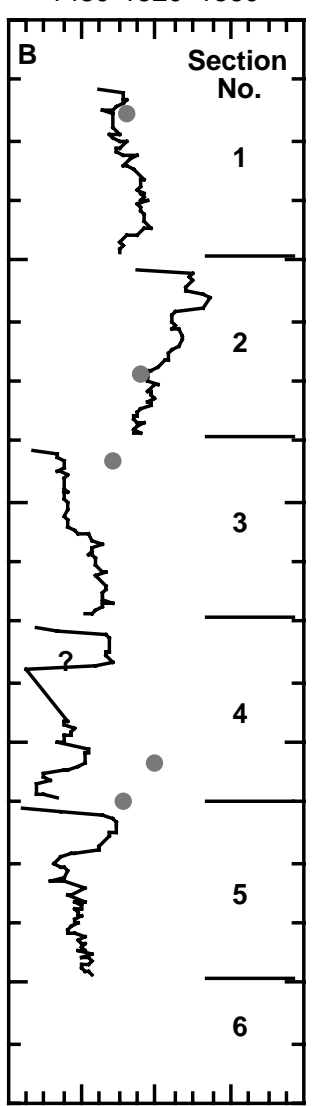

P-wave velocity $(\mathrm{m} / \mathrm{s})$

148015201560

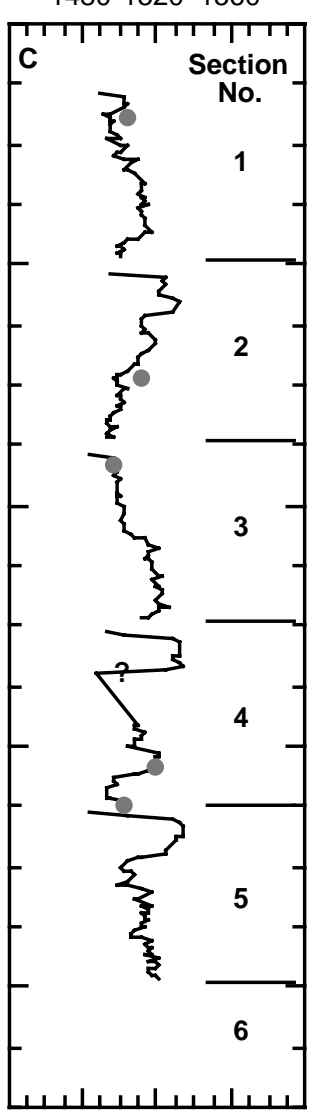

1485150015151530

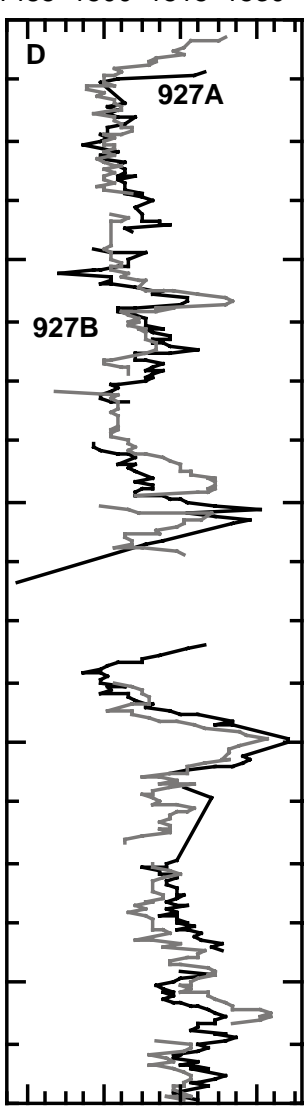

1485150015151530

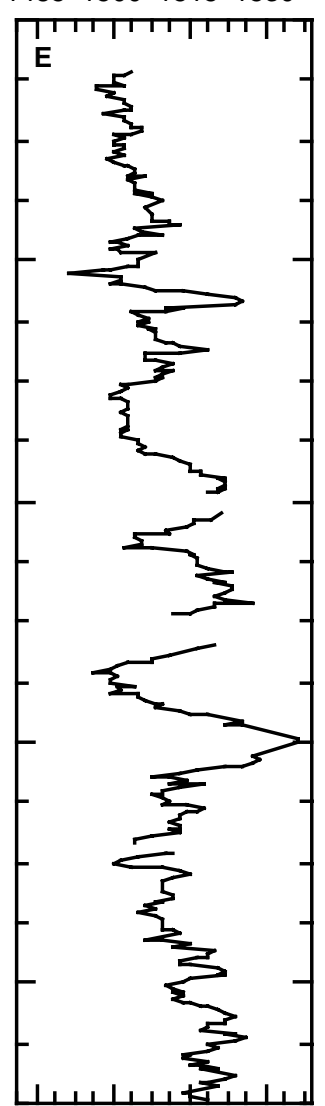

Figure 2. Processing sequence for the construction of a continuous $P$-wave velocity splice. A. Plot of raw data. The gray box indicates the range of plausible velocities. B. Data set after removal of wrong measurements (identified by signal amplitude). C. Adjustment of the continuous velocity record and discrete measurements (solid circles). D. Comparison of records from parallel holes vs. composite depth (mcd). E. Splice.

disintegrate. Thus, material moves from the coarse fraction into the finer fractions and decreases the preservation index (Yasuda et al., 1993).

To calculate accumulation rates of biogenous and terrigenous sediments, dry bulk density was estimated from GRAPE-density by assuming a grain density of $2.65 \mathrm{~g} / \mathrm{cm}^{3}$. Average values for glacial and interglacial periods were calculated.

\section{Spectral Analyses}

Records of $P$-wave velocity, magnetic susceptibility, carbonate accumulation rate, preservation index, and terrigenous accumulation rate from Sites 927 and 928 were converted from the depth to the time domain using a high-resolution, orbitally tuned stratigraphy (Bickert et al., Chapter 16, this volume). Afterwards, data were analyzed in the frequency domain using the Blackman-Tukey technique (Jenkins and Watts, 1968). Spectra were generated for three different time slices0-1200 k.y., 0-775 k.y., and 776-1200 k.y.-using 2-k.y. interpolated time steps and $30 \%$ lag. Bandwidths for the three time slices are 0.004, 0.006, and 0.011 cycles/k.y., respectively.

Additional evolutionary spectra of magnetic susceptibility and velocity records were generated. The first spectrum was calculated for the time interval 0-400 k.y. and has a position at $0 \mathrm{k} . \mathrm{y}$. on the time axis. Each successive spectrum represents an offset of $50 \mathrm{k} . \mathrm{y}$. and a 400 k.y. window ( 0.5 k.y. time intervals, $30 \%$ lag, 0.0125 cycles/k.y. bandwidth). The variance density values were contoured and grey shaded using spline interpolation. Darker colors mark higher variance densities.

\section{RESULTS AND DISCUSSION Sedimentary Processes at Ceara Rise}

Three principal sedimentation factors control the sedimentary regime at the Ceara Rise: carbonate productivity, carbonate dissolution, and supply of terrigenous minerals. At Site 927 (3315 mbsl) both biogenous input (indicated by carbonate accumulation rates, Table 1) and terrigenous dilution (indicated by siliciclastic accumulation rates, Table 1) are significantly higher than at Site 928 (4012 mbsl). Because the drilling locations of Sites 927 and 928 are very close together we assume that temporal changes in carbonate productivity run parallel at both sites. Thus, the lower $\mathrm{CaCO}_{3}$ accumulation at Site 928 is probably caused by enhanced dissolution of carbonate with depth (indicated also by a lower preservation index, Table 1). The terrigenous material at Sites 927 and 928 consists of fine-grained minerals derived from the Amazon delta, which is located $800 \mathrm{~km}$ southwest of Ceara Rise. Hence, the lower siliciclastic accumulation rates at Site 928 could possibly be explained by its position farther away from the coast. This sedimentation pattern - a high biogenous input with a high dilution due to terrigenous input at Site 927 and a low biogenous input with a low ter- 
Table 1. Comparison of sedimentological and physical parameters from glacial to interglacial periods at Sites 927 and 928.

\begin{tabular}{|c|c|c|c|c|}
\hline & \multicolumn{2}{|c|}{ Site 927} & \multicolumn{2}{|c|}{ Site 928} \\
\hline & Interglacial & Glacial & Interglacial & Glacial \\
\hline Sedimentation rate $(\mathrm{cm} / \mathrm{k} . \mathrm{y})$. & $\varnothing=4.61(4.05-5.81)$ & $\varnothing=4.59(4.05-5.81)$ & $\varnothing=3.86(3.37-4.81)$ & $\varnothing=3.83(3.37-4.81)$ \\
\hline$P$-wave velocity $(\mathrm{m} / \mathrm{s})$ & $\emptyset=1506(1481-1536)$ & $\varnothing=1500(1479-1516)$ & $\emptyset=1497(1474-1524)$ & $\varnothing=1495(1479-1521)$ \\
\hline GRAPE density $\left(\mathrm{g} / \mathrm{cm}^{3}\right)$ & $\varnothing=1.60(1.43-1.66)$ & $\varnothing=1.60(1.43-1.58)$ & $\varnothing=1.60(1.41-1.71)$ & $\varnothing=1.60(1.41-1.71)$ \\
\hline Magnetic susceptibility $\left(10^{-6} \mathrm{SI}\right)$ & $\varnothing=170(38-300)$ & $\varnothing=200(54-377)$ & $\varnothing=146(15-293)$ & $\varnothing=170(62-431)$ \\
\hline $\mathrm{CaCO}_{3}$ content $(\%)$ & $\emptyset=32(10-66)$ & $\varnothing=26(9-56)$ & $\varnothing=31(7-63)$ & $\varnothing=25(9-56)$ \\
\hline Sand content $(\%)$ & $\varnothing=10(1-28)$ & $\varnothing=6(0.5-21)$ & $\varnothing=7(0.5-27)$ & $\varnothing=6(0.3-24)$ \\
\hline Preservation index (\%) & $\varnothing=29(6-95)$ & $\emptyset=22(4-57)$ & $\emptyset=22(3-52)$ & $\emptyset=17(3-53)$ \\
\hline $\mathrm{CaCO}_{3}$ accumulation rate $\left(\mathrm{g} / \mathrm{cm}^{2} / \mathrm{k}\right.$.y. $)$ & $\emptyset=1.37(0.36-2.98)$ & $\emptyset=1.12(0.31-2.25)$ & $\emptyset=1.09(0.24-2.74)$ & $\emptyset=0.88(0.09-1.94)$ \\
\hline Sand accumulation rate $\left(\mathrm{g} / \mathrm{cm}^{2} / \mathrm{k} . \mathrm{y}.\right)$ & $\varnothing=0.41(0.04-1.24)$ & $\varnothing=0.26(0.02-0.85)$ & $\varnothing=0.27(0.01-1.05)$ & $\varnothing=0.17(0.01-0.84)$ \\
\hline Siliclastic accumulation rate $\left(\mathrm{g} / \mathrm{cm}^{2} / \mathrm{k}\right.$.y. $)$ & $\emptyset=2.90(1.42-4.39)$ & $\emptyset=3.14(1.73-4.11)$ & $\emptyset=2.46(1.42-3.48)$ & $\emptyset=2.64(1.58-3.46)$ \\
\hline
\end{tabular}

Note: Average values (Ø) for even and uneven isotope stages were calculated based on oxygen isotope stage boundary ages summarized by Weaver (1993). The number of measurements used to determine the values is 322 for glacials and 278 for interglacials.

rigenous dilution at Site 928-leads to a similar sediment composition at Sites 927 and 928. Differences in carbonate content between sites are only $1 \%-3 \%$ (Table1).

Both sites show marked changes in biogenous and terrigenous sediment accumulation from the glacial to interglacial periods of the Pleistocene. During interglacials, average carbonate accumulation rates are $1.37 \mathrm{~g} / \mathrm{cm}^{2} / \mathrm{k}$.y. at Site 927 and $1.09 \mathrm{~g} / \mathrm{cm}^{2} / \mathrm{k}$.y. at Site 928 , while siliciclastic accumulation rates are $2.90 \mathrm{~g} / \mathrm{cm}^{2} / \mathrm{k}$.y and $2.46 \mathrm{~g} /$ $\mathrm{cm}^{2} / \mathrm{k} . \mathrm{y}$, respectively (Table 1 ). In contrast, glacials are characterized by lower carbonate accumulation rates $\left(1.12 \mathrm{~g} / \mathrm{cm}^{2} / \mathrm{k}\right.$.y. at Site 927 and $0.88 \mathrm{~g} / \mathrm{cm}^{2} / \mathrm{k}$.y. at Site 928$)$ and higher terrigenous input $(3.14 \mathrm{~g} /$ $\mathrm{cm}^{2} / \mathrm{k}$.y. at Site 927 and $2.64 \mathrm{~g} / \mathrm{cm}^{2} / \mathrm{k}$.y. at Site 928 ). Low carbonate accumulation during glacials is caused by lower carbonate productivity as indicated by the relative abundance of the calcareous nannofossil Florisphaera profunda (Bassinot et al., this volume) and by higher carbonate dissolution, which is seen in the preservation index (Table 1). This is most probably caused by decreased production of glacial North Atlantic Deep Water (NADW) and the related extension of corrosive Antarctic Bottom Water (AABW) (e.g., Oppo and Fairbanks, 1987; Curry and Lohmann, 1990). On the other hand, high siliciclastic accumulation rates during glacials are probably caused by an increasing supply of terrigenous clays from the Amazon River into the western Atlantic during sea level low-stands. Sediment records from the Amazon Fan provide evidence that fluctuations in the supply of Amazon sediments were mainly controlled by glacio-eustatic sea-level changes (Flood, Piper, Klaus, et al., 1995).

\section{Sedimentological Control Mechanisms on Velocity Changes}

Figure 3 shows the $P$-wave velocity records for Sites 927 and 928. The data sets are the result of spliced records from multiple holes at each site. Both records represent the time interval from 0 to $1.2 \mathrm{~m} . \mathrm{y}$., and the corrected continuous PWL measurements are plotted in comparison to the discrete DSV data (solid circles). Because of the higher average sedimentation rate at Site $927(4.6 \mathrm{~cm} / \mathrm{k}$.y. compared to 3.8 $\mathrm{cm} / \mathrm{k} . \mathrm{y}$. at Site 928 ) the velocity record of this site represents a longer sediment column. The velocity gradient at Site $927\left(1.83 \mathrm{~s}^{-1}\right)$ is significantly higher than at Site $928\left(1.34 \mathrm{~s}^{-1}\right)$ due to a higher degree of sediment compaction at Site 927. So far, the constructed splices represent the longest continuous high-resolution velocity records for the equatorial Atlantic and offer an excellent opportunity to extend the existing studies of acoustic sediment properties (e.g., Mienert et al., 1988) back to oxygen isotope Stage 42.

Figure 4 shows a comparison of the continuous $P$-wave velocity records constructed for Sites 927 and 928 to other high-resolution data sets of sediment properties vs. composite depth (mcd). Bickert et al. (Chapter 16, this volume) provide a high-resolution stratigraphy for Sites 927 and 928 obtained from peak to peak comparisons of the magnetic susceptibility curves with the orbitally tuned record of Site
926. The age-depth relationships for the last 1.2 m.y. at Sites 927 and 928 are shown in Figure 5. This stratigraphic framework was used to construct equally sampled ( 2 k.y. spacing) continuous time series of all measured records for the interval 0-1.2 m.y. (Fig. 6). Isotope stage boundaries down to stage 42 were obtained from Weaver (1993) and are indicated by dashed lines.

In the detrended record of site $927, P$-wave velocity $\left(V_{p}\right)$ is 1503 $\mathrm{m} / \mathrm{s}$ in average with a range between $1479 \mathrm{~m} / \mathrm{s}$ and $1536 \mathrm{~m} / \mathrm{s}$. At Site 928 , velocity is slightly lower (average $1496 \mathrm{~m} / \mathrm{s}$ ) with less variability $(1474-1524 \mathrm{~m} / \mathrm{s})$. Distinct maxima in $P$-wave velocity $\left(V_{p}>1515\right.$ $\mathrm{m} / \mathrm{s}$ ) at both sites are associated with large climatic fluctuations during the Brunhes epoch and occur at the end of interglacial Stages 5, $7,9,11$, and 15 . Maximum $P$-wave velocities clearly correlate with maxima in the sediment sand fraction (>15\%, Fig. 6), in the carbonate content $(>40 \%)$. Carbonate content fluctuates between $9 \%$ and $66 \%$ at Site 927 (Fig. 6) and between $7 \%$ and 63\% at Site 928 (Fig. 6 ). Because the sediment fraction $>63 \mu \mathrm{m}$ consists almost entirely of sand-sized foraminifers, the sand content strongly co-varies with carbonate content. Maximum sand content values are up to $28 \%$ at Site 927 and $27 \%$ at Site 928 while minima are below $1 \%$ at both sites. Higher temporal variabilities of $P$-wave velocity, sediment coarse fraction, and $\mathrm{CaCO}_{3}$ content parallel interglacial isotope stages. On the other hand, glacial isotope stages are characterized by lower values with less variability (Fig. 6, Table 1). Maxima in the preservation index also correlate with high velocities, but high indices are not always mirrored in the velocity record. The correlation is clearer at the deeper Site 928. Furthermore, interglacial velocity maxima correspond to distinct negative excursions in the magnetic susceptibility record $\left(<140-10^{-6} \mathrm{SI}\right)$ and to maxima in GRAPE bulk density (Fig. $6)$. While average susceptibility values are significantly higher for glacial intervals (Table 1), average GRAPE densities show no significant differences from glacial to interglacial periods (Table 1). In general, the GRAPE records suffered from drift problems during Leg 154 that were likely associated with the counting electronics of the scintillator (Curry, Shackleton, Richter, et al., 1994). GRAPE-densities at the Ceara Rise show very small amplitude changes and are not suitable as a prediction tool for carbonate content, as has been reported for Pacific and east Atlantic regions (e.g., Herbert and Mayer, 1991).

There is strong evidence that the coarse fraction $(>63 \mu \mathrm{m})$ is the most effective parameter in controlling $P$-wave velocity changes in marine sediments (e.g. Hamilton, 1974), because high concentrations of sand strongly increase the elastic rigidity $(\mu)$ of the sediment (Morton, 1975). As a result, a positive relationship between sand content $(>63 \mu \mathrm{m})$ and $P$-wave velocity has often been reported in pelagic carbonates (e.g., Hamilton, et al., 1982; Mienert and Bloemendal, 1989; Bassinot, 1993). Covarying records of $P$-wave velocity and grain size from Sites 927 and 928 clearly confirm these results for the Ceara Rise (Fig. 6). Higher accumulation rates of sand-sized foraminifers 


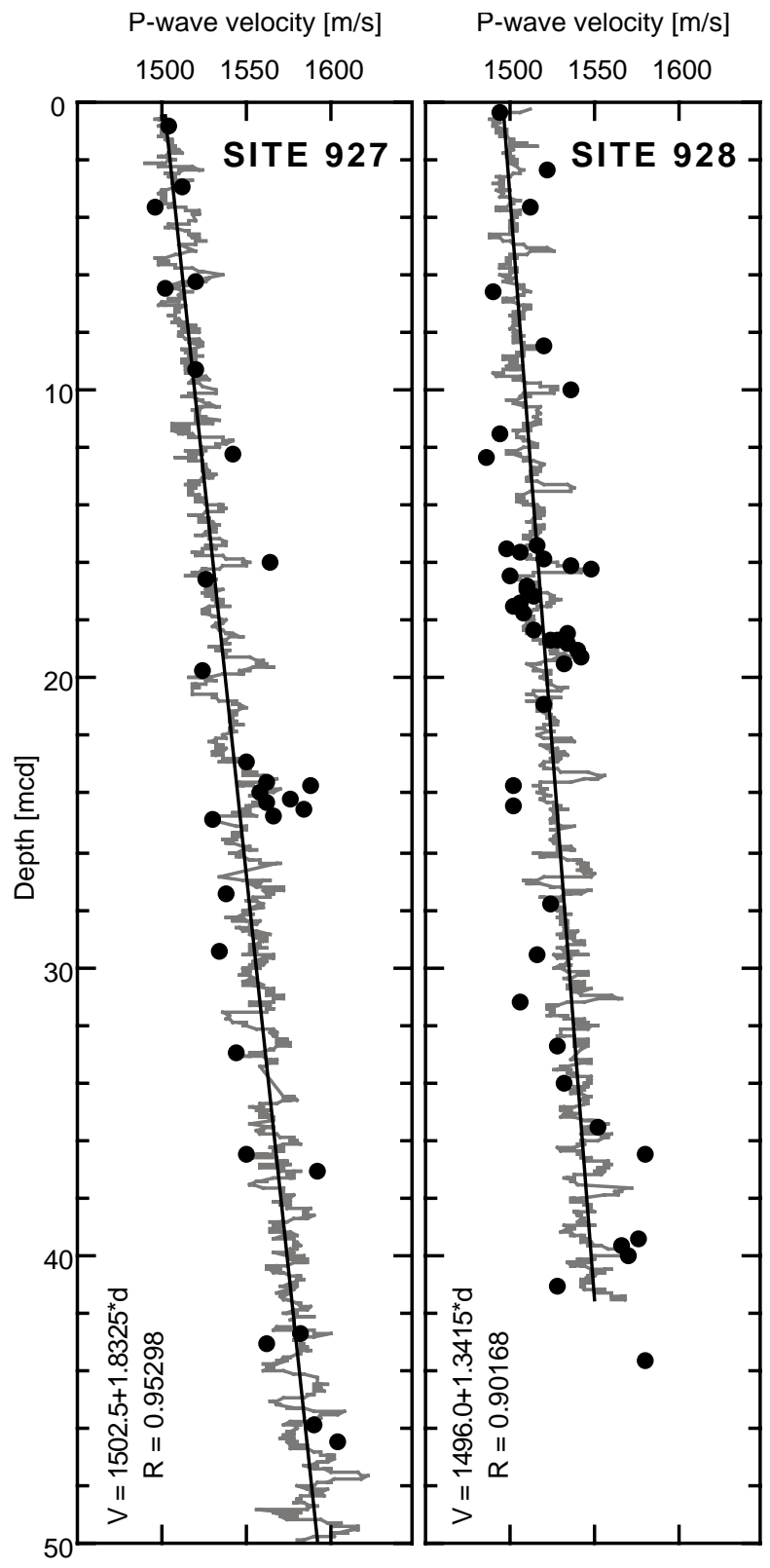

Figure 3. Continuous velocity records for Sites 927 and 928 in comparison to the discrete DSV-data (solid circles). Records at both sites represent the time interval from 0 to $1.2 \mathrm{Ma}$. Note the higher average sedimentation rate at Site $927(4.6 \mathrm{~cm} / \mathrm{k} . y$. compared to $3.8 \mathrm{~cm} / \mathrm{k} . \mathrm{y}$. at Site 928$)$ and the higher velocity gradient.

during interglacials increase the rigidity and subsequently the compressional velocity of the sediment. Mienert et al. (1988) pointed out that a linear relationship exists between grain size and velocity, but they showed that this relationship falls apart below $10 \%$ sand content. At both investigated sites at the Ceara Rise the average sand content is below $10 \%$ (see Table 1, 8.0\% at Site 927, 6.2\% at Site 928), which may explain the relatively low correlation coefficients between sand content and velocity ( 0.55 at Site $927,0.43$ at Site 928 ).

Both processes that led to an increase in $P$-wave velocity during interglacials, higher carbonate accumulation and decreased dilution by lower terrigenous input, also caused a decrease in magnetic susceptibility. Because the magnetic signal is carried only by the terrigenous component, a higher carbonate concentration decreases the concentration of magnetic minerals. However, velocity and magnetic susceptibility records are not always inversely correlated. This indicates that velocity is not only influenced by the changing ratio of biogenous to terrigenous material but also reflects breakage of foraminifers caused by dissolution or changes in the coccolith to foraminifer ratio. These processes could change the amount of sand sized foraminifers in the sediment without changing the carbonate content and subsequently are not reflected in the magnetic susceptibility, but in the velocity record. Because carbonate dissolution, as indicated by the preservation index (Fig 6), is controlled by the depth of the lysocline at Ceara Rise, the velocity records also reflect temporal changes in the mixing of North Atlantic Deep Water (NADW) and Antarctic Bottom Water (AABW). On the other hand, grain-size distribution and hence the velocity is also controlled by carbonate productivity. Because temporal variations in productivity (higher values during interglacials, Bassinot et al., this volume) are assumed to be the same at both sites, we conclude that the lower average velocities measured at the deeper Site 928 (Table 1) are caused by enhanced dissolution. However, from the data presented in Figure 6 and Table 1 alone we can not decide whether the velocity records - apart from the dilution effect-are more affected by dissolution or by productivity. To address this question frequency spectra of velocity records and sedimentological parameters were generated and compared.

\section{Spectral Analyses of Physical Property Time Series}

In Figure 7, variance density spectra calculated for the whole velocity series $(0-1.2$ m.y.) of Sites 927 and 928 are compared to spectra of magnetic susceptibility, $\mathrm{CaCO}_{3}$ accumulation rate, preservation index, and siliciclastic accumulation rate. Because the investigated time slice from 0 to 1.2 m.y. includes a prominent Pleistocene transition, from moderate 41-k.y. cyclicity in climate to larger amplitude and longer duration climate cycles, we also present separate spectra for the Brunhes (0-775 k.y., age of magnetic reversal given by Shackleton et al., 1990; Bassinot et al., 1994) and late Matuyama (775-1200 k.y.) time intervals. The development of changes in variance density with time are shown in the evolutionary spectra based on magnetic susceptibility and velocity records from Sites 927 and 928 and are presented as grey shaded contour plots (Fig. 8).

The clear presence of variance density maxima at primary Milankovitch frequencies of 19,23, 41 and 100 k.y. in the spectra of the velocity record from Site 927 (Fig. 7, 8) again emphasizes that paleoclimatic information is contained in this time series. Besides the 100-k.y. cyclicity for the Brunhes epoch, cyclic fluctuations in all parameters responded with nearly equal concentration of variance in the precession and obliquity bands. The tilt-related 41-k.y. cyclicity implies that changes in sediment composition, as indicated by carbonate accumulation rates, and subsequently in velocity are linked to highlatitude phenomena (Short et al., 1991). Siliciclastic accumulation rate changes in the Ceara Rise area are most likely associated with sea level changes caused by variations in global ice volume (Flood, Piper, Klaus et al., 1995). The precessional band, on the other hand, is more weakly represented in ice volume changes, as indicated by benthic oxygen isotope records from equatorial areas (e.g., Bassinot et al., 1994). Thus, physical property changes at 23-k.y. and 19-k.y. periods are probably more controlled by low-latitude (equatorial) phenomena like changes in the continental climate of South America (Tiedemann and Franz, this volume).

While the spectrum of magnetic susceptibility is dominated by the 100-k.y. cyclicity, the velocity record shows a stronger response in the obliquity band. Strong similarity in the shape of the velocity and carbonate accumulation spectra at Site 927 is observed in all investigated time slices (Fig. 7). Because the 100-k.y. cyclicity, which strongly dominated the preservation index record, is not observed in the velocity spectra, it suggests that velocity changes at Site 927 are more strongly influenced by changes in productivity than by dissolu- 
SITE 927

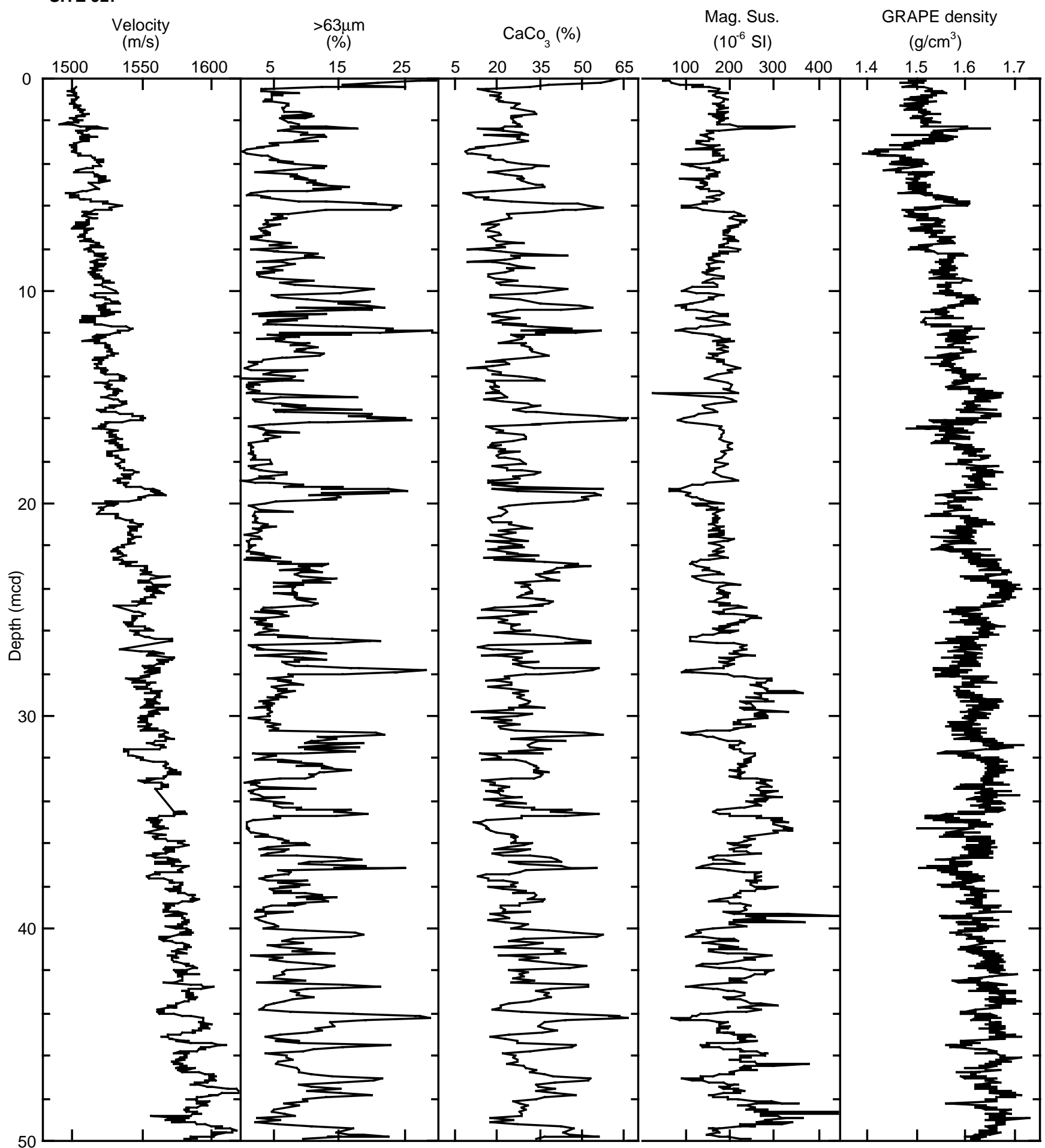

Figure 4. Spliced records of $P$-wave velocity, GRAPE density and magnetic susceptibility from Site 927 and Site 928 plotted vs. composite depth in comparison to measurements of sediment coarse fraction $(>63 \mu \mathrm{m})$ and carbonate content $\left(\mathrm{CaCO}_{3}\right)$.

tion. The evolutionary spectrum of the velocity record from Site 927 (Fig. 8) illustrates the transition from an obliquity to an eccentricity dominated sedimentary system during the Brunhes. During the last 200 k.y., the velocity record of Site 927 and Site 928 is dominated by periodicity in the precession band. In contrast, a strong 100-k.y. cyclicity in magnetic susceptibility at both sites is visible throughout the whole time span. The evolution in obliquity and precessional band is similar to the velocity spectrum of Site 927 .

At Site 928, which is much closer to the modern lysocline, the effect of enhanced carbonate dissolution resulted in a stronger 41-k.y. cyclicity (Fig. 7) in the preservation record. While the spectra of magnetic susceptibility, carbonate input, and terrigenous accumula- 


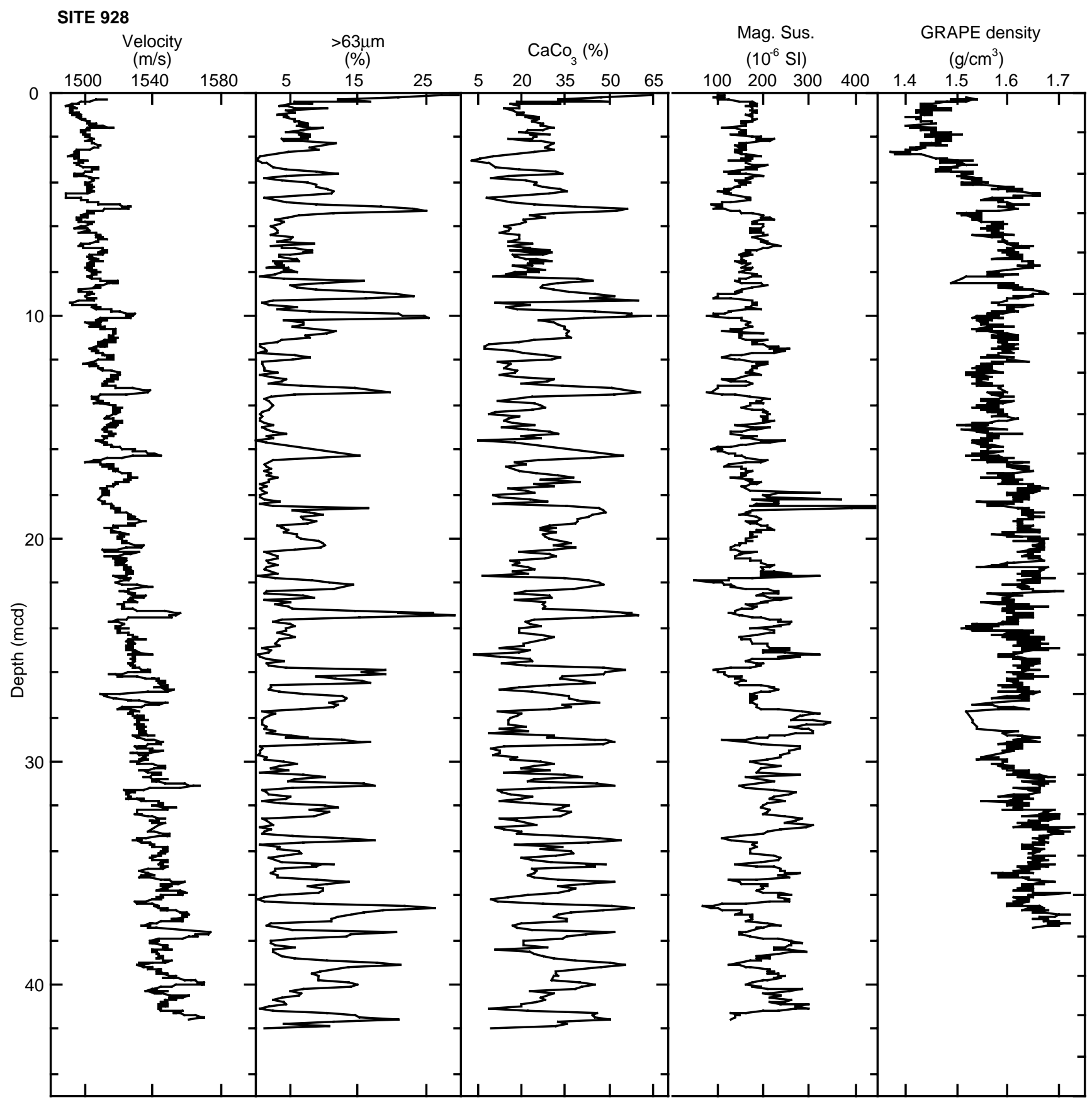

Figure 4 (continued).

tion are very similar at Site 928 and Site 927 , the $P$-wave velocity spectrum of Site 928 (Fig. 7) exhibits fundamental differences. Maximum variance density is not associated with typical Milankovitch frequencies, but is concentrated in between the obliquity and precession band (Fig. 8). Very little power is observed at 100 k.y. We interpret the observed changes in the velocity spectrum from Site 927 to Site 928 as a result of enhanced carbonate dissolution at Site 928. Glacial to interglacial differences in the average content of the coarse fraction at Site 928 are only $1 \%$ (Table 1), so that accurate tracking of climatic cycles with small to moderate amplitude is not possible with $P$-wave velocity measurements. However, larger amplitude climatic cycles (with larger sand content fluctuations) are still observed at orbital frequencies in the velocity spectrum. For example, the 100k.y. cycle is pronounced in the spectrum for the Brunhes of Site 928 (Fig. 7), and the variance maxima in precessional frequencies (19 and 23 k.y.) are dominant for the last 250 k.y. (Fig. 8).

\section{CONCLUSIONS}

Pleistocene sediments covering the Ceara Rise show high-frequency changes in the ratio of carbonate to clay content that indicate variations in the contribution of terrigenous material from the Amazon River as well as carbonate dissolution and productivity cycles. 


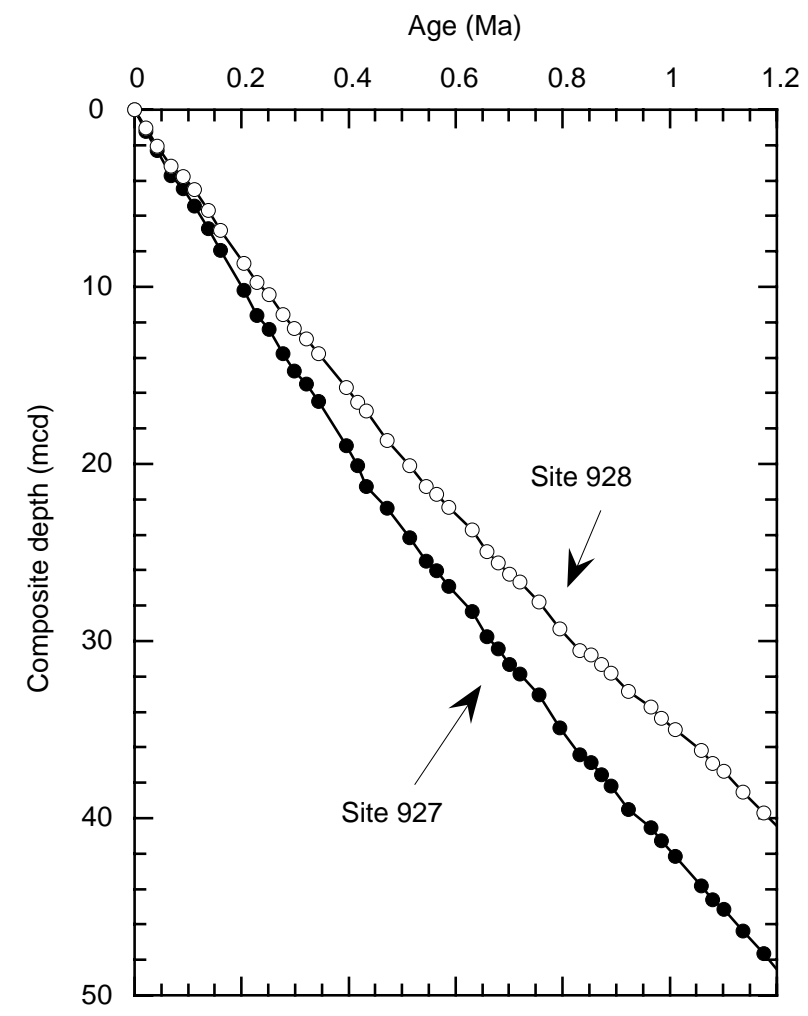

Figure 5. Plot of the age vs. depth models for the lower Pleistocene (0-1.2 Ma) derived from orbital tuning of the magnetic susceptibility record (Bickert et al., Chapter 16, this volume). Control points are indicated by circles.

We examined the $P$-wave logger (PWL) records of ODP Sites 927 and 928 to explore their potential as a paleoceanographic tool in this sedimentary regime.

Although each velocity record from a single hole contains a large amount of erroneous data, we were able to construct high-resolution continuous series by splicing together records from multiple holes at a single site. The generated records extend back to oxygen isotope stage 42 and represent the longest high-resolution sonic velocity records for the equatorial Atlantic. Maxima in $P$-wave velocity are associated with interglacial pelagic sedimentation and are applicable for inter-site correlation. In contrast, glacial periods are characterized by low velocities.

Comparison of the $P$-wave velocity measurements with other high-resolution physical property data and sedimentological parameters reveals that, as expected, in carbonate sediments changes in velocity are controlled by the coarse fraction content $(>63 \mu \mathrm{m})$ of the sediment. Because the coarse fraction on Ceara Rise is almost exclusively composed of foraminifer tests, there is a positive correlation between velocity and $\mathrm{CaCO}_{3}$ content and thus a negative correlation between velocity and magnetic susceptibility (which mainly reflects dilution of pelagic carbonate by terrigenous clays). In the frequency domain all investigated physical and sedimentological parameters show the clear presence of Milankovitch cycles of 19 and 23 k.y. (precession), 41 k.y. (obliquity), and 100 k.y. (eccentricity). At Site 927 , well above the present lysocline, a large similarity in spectra of $P$-wave velocity and carbonate accumulation is observed. However, the dominance of the 100-k.y. cyclicity observed in the preservation index is not reflected in the velocity spectrum. This possibly indicates a stronger influence of productivity changes on velocity at this location. At Site 928, which was drilled in a water depth close to the present lysocline, variance density maxima in $P$-wave velocity are concentrated between obliquity and precessional bands and are not associated with primary Milankovitch frequencies. We explain this with lower fluctuations in sand content $(>63 \mu \mathrm{m})$ as a result of enhanced carbonate dissolution.

\section{ACKNOWLEDGMENTS}

We are grateful to Bill Curry, Jim Cullen, Thorsten Bickert and Edith Vincent for providing carbonate and grain size data; to Roy Wilkens and one anonymous reviewer for critically reading the manuscript; to Ralf Tiedemann for fruitful discussions about spectral analyses; and to the crew, technicians, and scientific staff of ODP Leg 154 for collecting the sediment cores. This study was supported by the Deutsche Forschungsgemeinschaft.

\section{REFERENCES}

Bassinot, F.C., 1993. Sonostratigraphy of tropical Indian Ocean giant piston cores: toward a rapid and high-resolution tool for tracking dissolution cycles in Pleistocene carbonate sediments. Earth Planet. Sci. Lett., 120:327-344.

Bassinot, F.C., Labeyrie, L.D., Vincent, E., Quidelleur, X., Shackleton, N.J., and Lancelot, Y., 1994. The astronomical theory of climate and the age of the Brunhes-Matuyama magnetic reversal. Earth Planet. Sci. Lett., 126:91-108.

Boyce, R.E., 1976. Definitions and laboratory techniques of compressional sound velocity parameters and wet-water content, wet-bulk density, and porosity parameters by gravimetric and gamma-ray attenuation techniques. In Schlanger, S.O., Jackson, E.D., et al., Init. Repts. DSDP, 33: Washington (U.S. Govt. Printing Office), 931-958.

Boyce, R.E., and Bode, G.W., 1972. Carbon and carbonate analyses, Leg 9, Deep Sea Drilling Project. In Hays, J.D., et al., Init. Repts. DSDP, 9: Washington (U.S. Govt. Printing Office), 797-816.

Curry, W.B., and Lohmann, G.P., 1990. Reconstructing past particle fluxes in the tropical Atlantic Ocean. Paleoceanography, 5:487-505.

Curry, W.B., Shackleton, N.J., Richter, C., et al., 1995. Proc. ODP, Init. Repts., 154: College Station, TX (Ocean Drilling Program).

deMenocal, P., and King, T., 1995. Paleoclimate information from sediments and downhole logs, I: chronostratigraphic applications [paper presented at the 5th Int. Conf. Paleoceanogr., ICP V, Halifax, October 1995].

Flood, R.D., Piper, D.J.W., Klaus, A., et al., 1995. Proc. ODP, Init. Repts., 155: College Station, TX (Ocean Drilling Program).

Hamilton, E.L., 1974. Prediction of deep-sea sediment properties: state of the art. In Inderbitzen, A.L. (Ed.), Deep-Sea Sediments: Physical and Mechanical Properties: New York (Plenum), 1-44.

Hamilton, E.L., Bachman, R.T., Berger, W.H., Johnson, T.C., and Mayer, L.A., 1982. Acoustic and related properties of calcareous deep-sea sediments. J. Sediment. Petrol., 52:733-753.

Herbert, T.D., and Mayer, L.A., 1991. Long climatic time series from sediment physical property measurements. J. Sediment. Petrol., 61:10891108 .

Hou, T., and Mayer, L.A., 1995. A new automated tool for building composite depth sections from multiply-cored drill sites [paper presented at 5th Int. Conf. Paleoceanogr., ICP V, Halifax, October 1995].

Jenkins, G.M., and Watts, D.G., 1968. Spectral Analysis and Its Applications: San Francisco (Holden Day).

Mayer, L.A., 1980. Deep-sea carbonates: physical property relationships and the origin of high-frequency acoustic reflectors. Mar. Geol., 38:165-183.

Mayer, L.A., 1991. Extraction of high-resolution carbonate data for paleoclimate reconstruction. Nature, 352:148-150.

Mayer, L.A., Courtney, R.C., and Moran, K., 1987. Ultrasonic measurements of marine sediment properties. Proc. Oceanogr., 1-139.

Mienert, J., 1986. Acoustic stratigraphy in the eastern equatorial Atlantic: on the development of deep-water circulation during the last 3.5 million years. "Meteor" Forschungsergeb., Reihe C, 40:19-86.

Mienert, J., and Bloemendal, J., 1989. A comparison of acoustic and rockmagnetic properties of equatorial Atlantic deep-sea sediments: paleoceanographic implications. Earth Planet. Sci. Lett., 94:291-300. 
Mienert, J., Curry, W.B., and Sarnthein, M., 1988. Sonostratigraphic records from equatorial Atlantic deep-sea carbonates: paleoceanographic and climatic relationships. Mar. Geol., 83:9-20.

Morton, R.W., 1975. Sound velocity in carbonate sediments from the Whiting Basin, Puerto Rico. Mar. Geol., 19:1-17.

Oppo, D.W., and Fairbanks, R.G., 1987. Variability in the deep and intermediate water circulation of the Atlantic Ocean during the past 25,000 years: Northern Hemisphere modulation of the Southern Ocean. Earth Planet. Sci. Lett., 86:1-15.

Robinson, S.G., Maslin, M.A., and McCave, I.N., 1995. Magnetic susceptibility variations in late Pleistocene deep-sea sediments of the N.E. Atlantic: implications for ice-rafting and paleocirculation at the last glacial maximum. Paleoceanography, 10:221-250.

Schultheiss, P.J., and McPhail, S.D., 1989. An automated $P$-wave logger for recording fine-scale compressional-wave velocity structures in sediments. In Ruddiman, W., Sarnthein, M., et al., Proc. ODP, Sci. Results, 108: College Station, TX (Ocean Drilling Program), 407-413.

Schultheiss, P.J., Mienert, J., and Shipboard Scientific Party, 1988. Wholecore $P$-wave velocity and gamma ray attenuation logs from Leg 108 (Site 657 through 668). In Ruddiman, W., Sarnthein, M., Baldauf, J., et al., Proc. ODP, Init. Repts., 108: College Station, TX (Ocean Drilling Program), 1015-1046.
Shackleton, N.J., Berger, A., and Peltier, W.A., 1990. An alternative astronomical calibration of the lower Pleistocene timescale based on ODP Site 677. Trans. R. Soc. Edinburgh: Earth Sci., 81:251-261.

Short, D.A., Mengel, J.G., Crowley, T.J., Hyde, W.T., and North, G.R., 1991. Filtering of Milankovitch Cycles by earth's geography. Quat. Res., 35: $157-173$.

Weaver, P.P.E., 1993. High resolution stratigraphy of marine Quaternary sequences. In Hailwood, E.A., and Kidd, R.B. (Eds.), High Resolution Stratigraphy. Geol. Soc. Spec. Publ. London, 70:137-153.

Yasuda, M., Berger, W.H., Wu, G., Burke, S., and Schmidt, H., 1993. Foraminifer preservation record for the last million years: Site 805, Ontong Java Plateau. In Berger, W.H., Kroenke, L.W., Mayer, L.A., et al., Proc. ODP, Sci. Results, 130: College Station, TX (Ocean Drilling Program), 491-508.

Date of initial receipt: 20 December 1995

Date of acceptance: 13 May 1996

Ms 154SR-130 
SITE 927

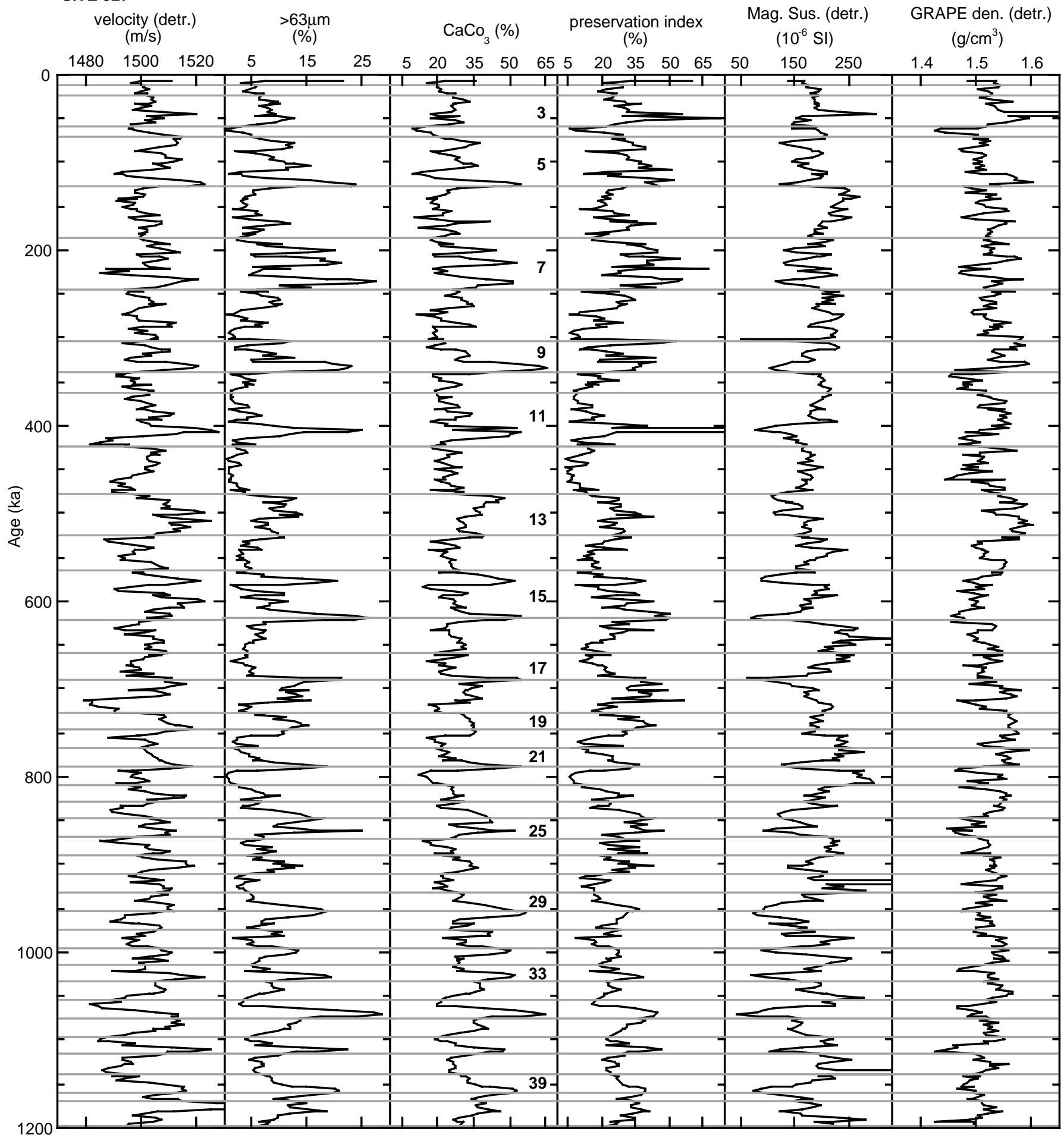

Figure 6. Equally sampled (2-k.y. spacing) continuous time series of $P$-wave velocity, sand content ( $>63 \mu \mathrm{m}), \mathrm{GRAPE}$ density, carbonate content $\left(\mathrm{CaCO}_{3}\right)$, preservation index, and magnetic susceptibility from Site 927 and Site 928 for the interval 0-1.2 Ma. Isotope stage boundaries down to Stage 42 were obtained from Weaver (1993) and are indicated by dashed lines. MST physical property records were detrended to remove lower frequency variability presumably not associated with climatic changes. 
SITE 928

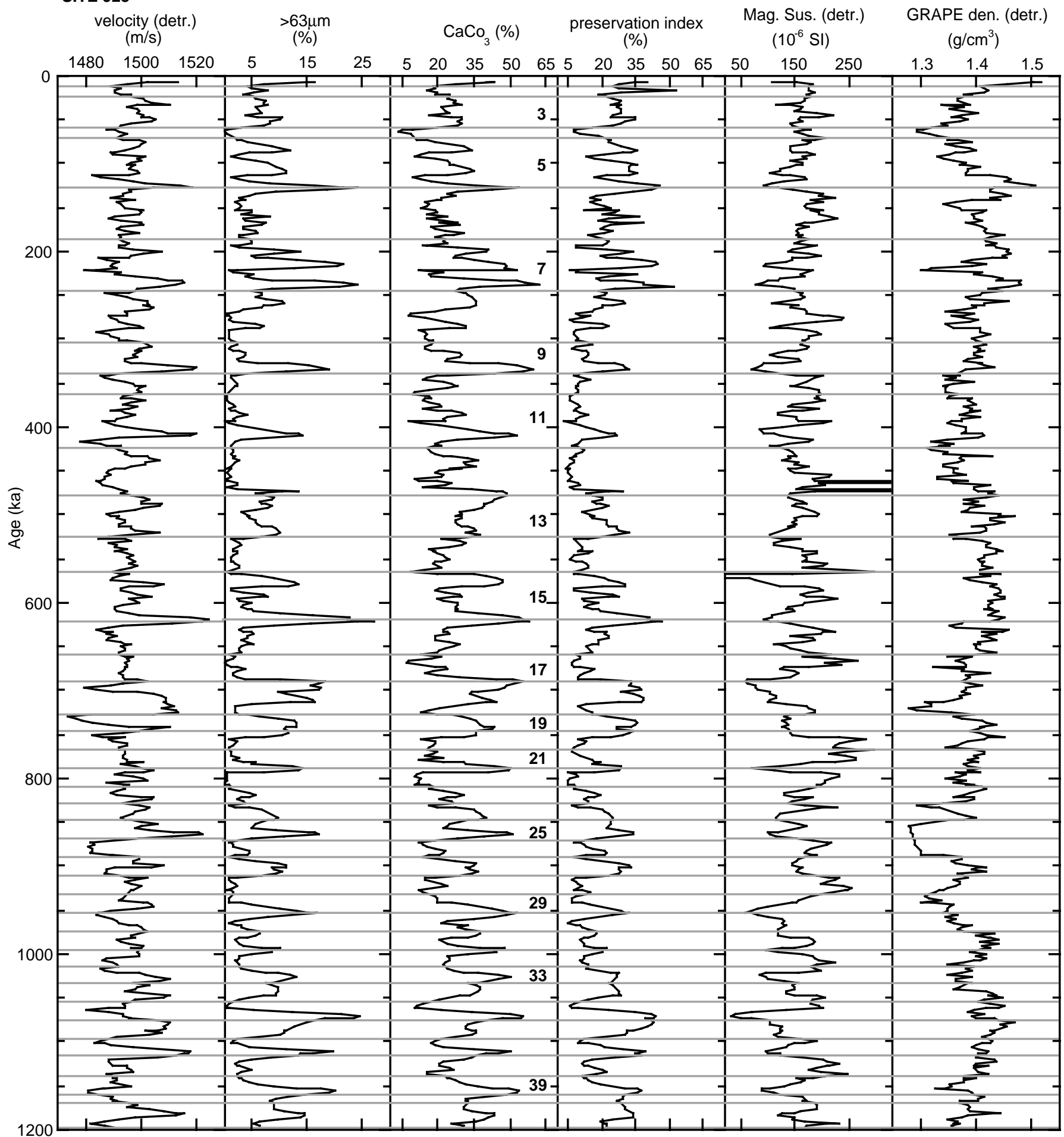

Figure 6 (continued). 


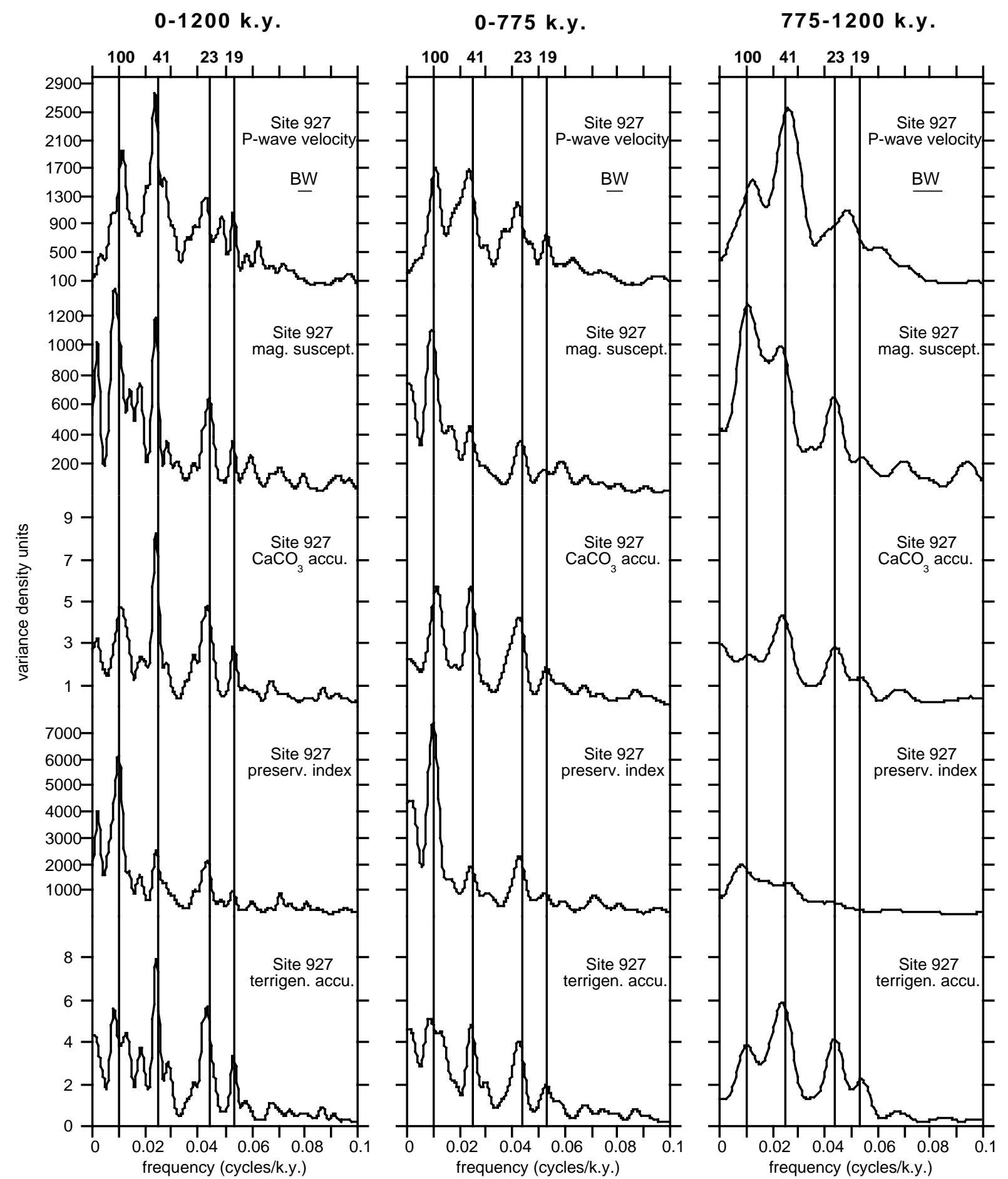

Figure 7. Variance density spectra of (from top to bottom) compressional-wave velocity, magnetic susceptibility, carbonate accumulation rate, preservation index, and terrigenous accumulation rate for Site 927 (this page) and Site 928 (following page). Spectra were generated for (from left to right) the whole series (0-1200 k.y.), as well as for Brunhes (0-775 k.y.), and Matuyama (776-1200 k.y.) intervals separately, using 2 k.y. time steps and 30\% lag. Bandwidth (BW) for the three time slices are indicated by horizontal bars. 
0-1200 k.y.

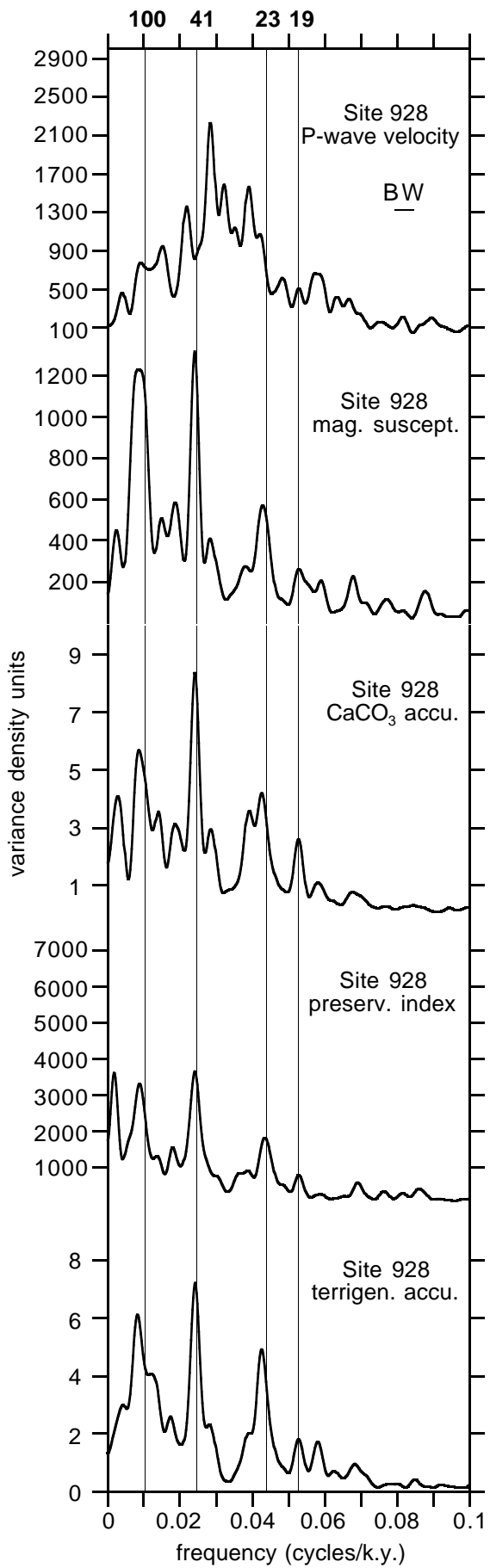

0-775 k.y.

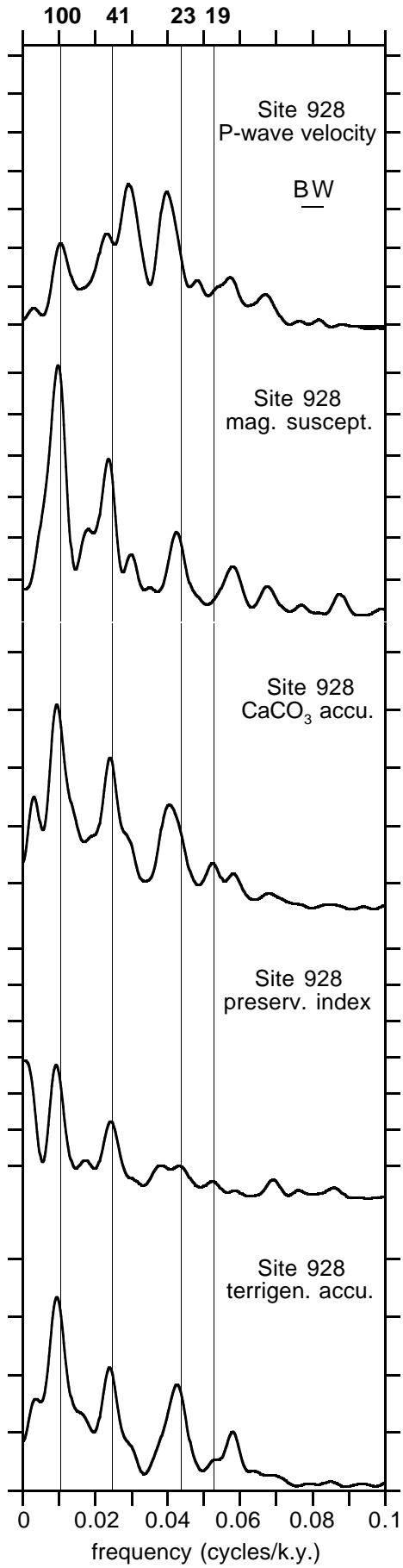

Figure 7 (continued).
776-1200 k.y.

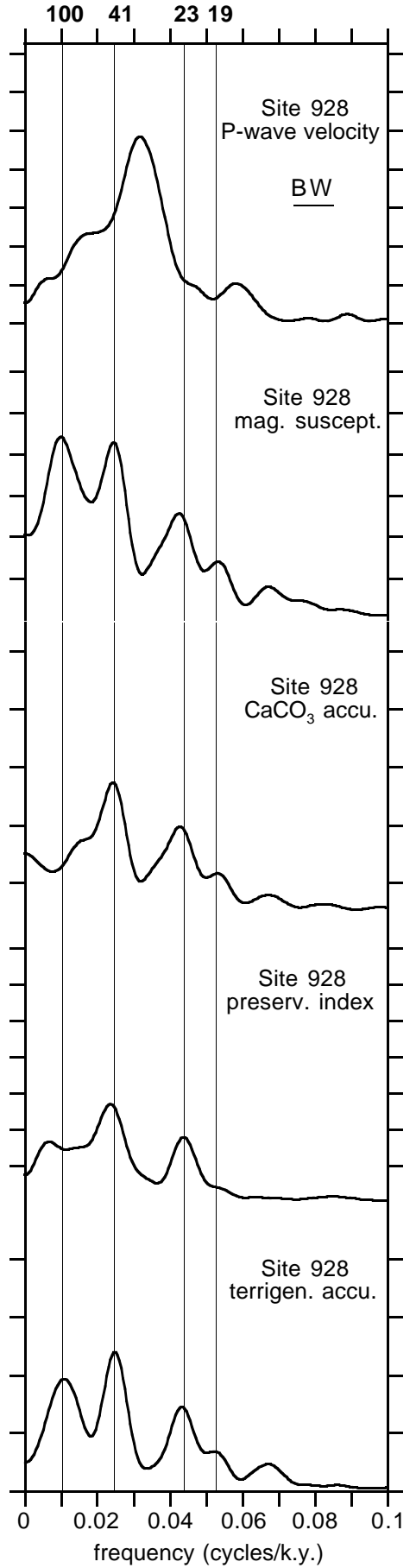



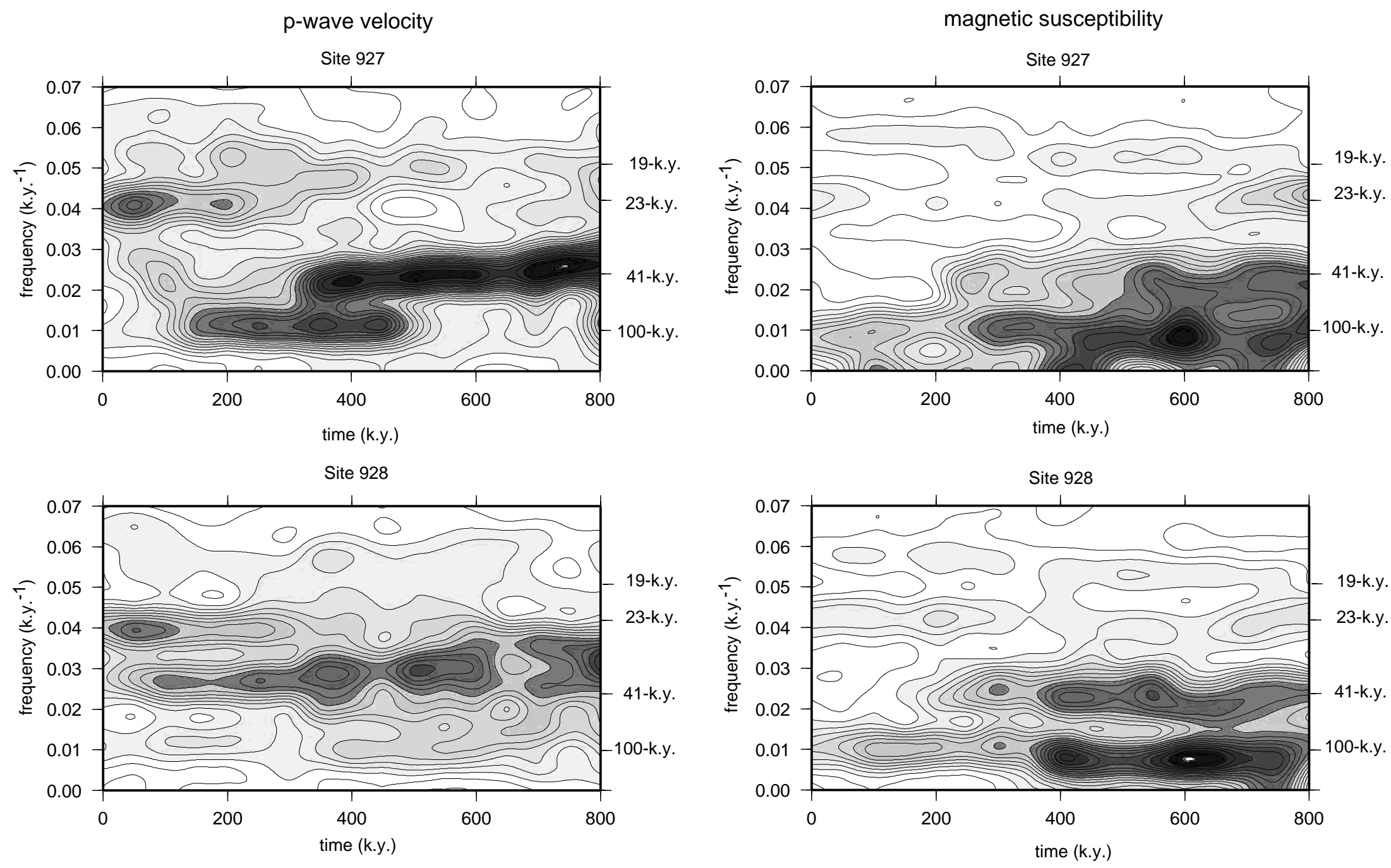

variance density (normalized)

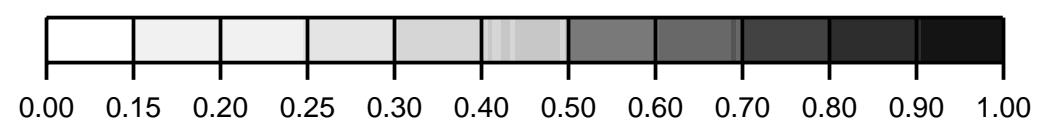

Figure 8. Evolutionary spectra calculated for velocity (left) and magnetic susceptibly (right) time series of Site 927 (top) and Site 928 (bottom). The first spectrum was calculated for the time interval $0-400$ k.y. and has a position at 0 k.y. on the time axis. Each successive spectrum represents an offset of 50 k.y. and a 400 k.y. window ( 0.5 k.y. time steps, $30 \%$ lag, 0.0125 cycles/k.y. bandwidth). The variance density values were contoured and gray shaded using spline interpolation. Darker colors mark higher variance densities. 